\title{
ANALYSIS OF CROP RESIDUES AVAILABILITY FOR ANIMAL FEED IN KEBBI STATE,
} NIGERIA

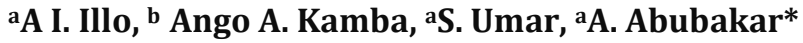 \\ ${ }^{a}$ Department of Agricultural Economics and Extension, Faculty of Agriculture, Kebbi State University of Science and \\ Technology, Aliero, Nigeria. \\ ${ }^{b}$ Department of Agricultural Extension and Rural Development, Faculty of Agriculture, Usmanu Danfodiyo University, \\ Sokoto, Nigeria.
}

\section{A B S T R A C T}

This study analyzed the use of crop residues in animal feeding in Kebbi state, Nigeria. Data for the study was generated through the use of structured questionnaire and three points Likert rating scale and data obtained was analyzed using descriptive statistics. Results of the study revealed that all $(100 \%)$ the respondents were male, active and productive in ages (18-47 years) with majority having non - formal education (Qur'anic education) and common mode of land acquisition being through inheritance (70\%). Findings of the study further revealed that the common crop residue utilized by the respondents was groundnut haulm $(40 \%)$ and both cowpea haulm and millet stalks $(20 \%)$ that were mostly (89\%) sourced from their farms, stored and preserved through baling (71\%). Majority (90\%) of the respondents infer that large proportion of the metabolizable energy is wasted during eating and digestion of low-quality crop residues. The study concluded that groundnut haulms and sorghum stalks were the common crop residues utilized for feeding animals, mostly stored and preserved locally with the use of silos and drums. The study recommends that government and the respondents should come up with modern storage and preservation methods of crop residues in order to improve its nutrient value and avoid spoilage.

Keywords: Analysis, crop residues, availability, animal Feed, Kebbi State, Nigeria.

\section{INTRODUCTION}

Crop residues are fibrous by-products which resulted from crop cultivation. These crops include leaves, leaf sheath and stems. Availability of crop residues at the farm level depends not just on production levels but also on a variety of social and economic factors (Alemu et al., 2006). Cook et al. (2005) augmented that land, crop and animal ownership patterns, cultural practices and the opportunities for market and non-market exchanges influences a farmer's access to the locally produced residues. Seasonal and inter-year variations in crop residues production can also have a marked effect on availability of the residues at a particular time of the year. Plant parts used for food and fiber, and crops grown for animal feed, do not produce most of the phytomass harvested annually by the world's agriculture as crop

* Corresponding Author:

Email: aakamba2@gmail.com

(C) 2018 ESci Journals Publishing. All rights reserved. residues do. More than half of all absolutely dry matter in the global harvest is in cereal and legume straws; stalks, leaves, and shoots of tuber, oil, sugar, and vegetable crops; and in pruning and litter of fruit and nut trees (Arntzen, 1994).

In developed countries, crop residues are largely returned to the soil or, in some instances, may be used for maintenance of beef cattle during the winter (Renard, 1997). When the bran and stover are used as animal feed, total metabolizable energy (ME) may be increased to over $56 \%$ and protein utilization to $28 \%$. In South Asia, crop residues are used as compost and mulch for crop production, bedding for livestock, and a substrate for growing mushrooms, fiber for paper manufacture and as fuel energy (Cook et al., 2005). In Semiarid sub-Saharan Africa, they are used to control wind erosion and in the construction of roofs, fences, granaries, beds and doormats. Generally, the substantial diversity that exists between production systems in 
resource endowments, availability of different feeds and types and levels of animal production creates different opportunities for the use of crop residues as animal feeds. In grass/rangelands, for example, crop residues play a minor role whereas they are very important in mixed crop/livestock system. Cowpea hay is the common crop residue utilized in the study area and wellcured cowpea haulms are useful feed and can make excellent hay, provided that the leaves are well preserved (too much exposure to the sun makes them fall off) and that the stems are adequately wilted Onwuka et al., 1997; FAO, 2013; Göhl, 1982). In Africa and Nigeria in particular, cowpea is primarily grown for its seeds and leaves and thus harvested when $75-80 \%$ of pods are dry, approximately 120-150 days after planting (Van - Rij, 1999). Successful harvesting of the crop is highly dependent on suitable weather and often the leaves are diseased or senescent at the time of harvest (Suttie, 2000). Cowpea can produce good yields of highquality dry matter. Under dry land conditions, yields of cowpea forage have ranged from $0.5 \mathrm{t} \mathrm{DM} /$ ha to over $4 \mathrm{t}$ $\mathrm{DM} /$ ha under favorable conditions. Farmers may harvest up to $0.4 \mathrm{t} / \mathrm{ha}$ of cowpea leaves in a few cuts with no noticeable reduction in seed yield. A potential yield of 4 $t /$ ha of hay can be achieved with good management from a pure stand of cowpea. However, the world average yield of cowpea fodder is $0.5 \mathrm{t} / \mathrm{ha}$ (air-dried leafy stems) (Madamba et al., 2006).

Most of the crop residues play a major role in the productive performance of livestock (Fialho et al., 1995). Crop residues are important among animals managed on ranges, since quantity and quality of herbage in the tropics is determined by the seasonal pattern of rainfall. Animals that depend on natural vegetation for nutrition suffer heavy weight loss during the dry season which coincides with its productive performance; as such there is need for the preservation of the crop residues for its subsequent utilization by the animals in the dry season (Deaville et al., 1994). Nevertheless, there is no doubt that a large part of the residual harvest is handled inappropriately, weakening the world's food-production capacity and contributing to undesirable biospheric change. Such malpractice is particularly common in lowincome countries, where inadequate amounts of residues are recycled while unacceptably large amounts of straws and stalks are burned, either in the fields or as household fuel.

Crop and livestock agriculture are important to the lives of most Nigerians because fifty to eighty percent of Nigerians are involved in crop, livestock, or croplivestock agriculture. Nigerian agriculture is dynamic as such farmers who were hitherto involved only in crop production have adopted crop-livestock production (Akinola et al., 2015). According to Agyemang et al. (1993) formally transhumant pastoralists are increasingly turning into agro-pastoralists. This change is largely spontaneous and is based on perceived reciprocal benefits that such a system offers.

More importantly that, the study area being in the Sudan Savannah agro-ecological zone of Nigeria experienced a single raining season in the year, as a result, most of the months of the year experience dry season. During this period of the year, grasses become dried, some of the leaves of the high plant either wilted or withered by the dry wind and some die up. Based on the above problems, animals in the area are left with nothing but scavenging on the dust bins or migrated to the southern part of the country or fed with preserved crop residues. Animal farmers of the study area are not devoid of most of these constraints and hence its crop residue availability, types of crop residue, method of preservation have to be evaluated to ascertain its productive potentials.

The need to improve utilization of crop residues in developing countries has received considerable attention in recent years, but there have been few studies (Kossila, 2018) on the availability of fibrous crop residues in relation to their potential for feeding livestock. This study therefore, pays more attention on analyzing crop residue availability for animal feed in the study area. It is against this background that this study provides answer to the listed objectives: (a) describe the socio-economic characteristics of the respondents (b) indentify the various type of crop residue available in the study area (c) examine the method of preservation of the crop residues and (d) evaluate the respondents' perception on the relevance of crop residues as animal feeds.

\section{RESEARCH METHODOLOGY}

Study Area: This research was conducted in Aliero Local Government Area of Kebbi State. The area is located in the south east of Kebbi State and lies between latitude $12016^{\prime}$ and 1202' $\mathrm{N}$ and Longitude 4027' and 4045'. The study area is located in the Sudan Savannah agroecological zone of Nigeria and it experiences serious moisture deficiency for greater part of the year. The climate of the area is generally characterized by high 
temperatures ranging between March and May, with annual temperature varying between $380 \mathrm{C}$ to $420 \mathrm{C}$ and the area experiences Harmatan wind between late November to early February, with temperatures as low as 23 0C. Rainfall usually begins early May and ends in late September or early October with mean annual rainfall varying between $500 \mathrm{~mm}$ to $800 \mathrm{~mm}$.

Occupation of the inhabitant of the area is mostly agrarian with about $70 \%$ of the population engaged in farming and selling of farm products (Nations Encyclopedia, 2018). The common crops grown in the area includes maize, millet, sorghum, groundnut, cowpea and vegetable crops like onion, lettuce, tomatoes spinach, pepper and animal husbandry and fishing activities.

Sampling Procedure and Sample Size: Exploratory survey was conducted to ascertain the users of crop residues in animal feeding. Kebbi State was found to have abundant livestock which include cattle, sheep, goats, camels, horses, donkeys and poultry. A survey of livestock potentials in the state ranks the state among the five states with the highest number of livestock. The state exports quite a substantial number of livestock to other states of Nigeria (OnlineNigeria, 2018).

The selected Local Government Area (LGA) was purposively selected for the study due to abundance of animals in the areas. From the selected LGA, five villages were randomly selected, and simple random sampling technique was also employed to select ten livestock farmers from each of the selected villages, making the sample size of the study to constitute 100 respondents.

Primary data for the study was collected through the use of structured questionnaire.

The contents (items) of the questionnaire were subjected to validity test by the experts in Agricultural Economics and Extension. Items used to measure the main variables of the study were also subjected to reliability tests and result obtained indicated that all the items had Cronbach alpha values of more than 7.0, revealing that the items used for measuring the study variables are fit to provide response to the variables. Samples of the questionnaire was pretested on the respondents through which some questions and items with ambiguous meanings were either removed or reframed to provide better response.

While the secondary information was sourced from text books, journals, and book of proceedings, official records and internet source. Likert rating scale was used to measure the attitudinal disposition of the respondents towards utilization of crop residues in feeding animals in the study area. Each attitudinal statement has a weight or a score attached to it based on five-point rating scale. Weights are usually assigned to the attitudinal statements so as to indicate the favorable attitudes or vice versa of the respondents (Blum and Naylor, 1984). Positive attitudinal statements are rated as Agree $=\mathrm{A}(3$ points), Undecided $=\mathrm{U}$ (2 points), Disagree $=\mathrm{DA}(1$ point) and vice versa for negative attitudinal statements. RESULTS AND DISCUSSION

Socio-Economic Characteristics of the Respondents: Findings in Table 1 show that all the respondents interviewed for the study were male. Discussion with the respondents reveals that the exclusion of the female farmers in the study was attributed to the traditional "Kulle" system of marriage practiced by Muslim dominated community in which female were not allowed to interact freely with male counterpart. Results of the study further revealed that $35 \%$ of the respondents were between the age of 28 - 37 years, while $10 \%$ of them were between the ages of 48 years and above mean age of 31years and above, implying that the respondents were in their active and productive ages. Table 1 further indicated that majority $(75 \%)$ of the respondents were married with most (65\%) of them acquired non-formal education while few $(35 \%)$ had formal education and majority $(60 \%)$ of whom were farmers.

Table 1. Distribution of Respondents According to Socio-economic Characteristics ( $\mathrm{n}=100)$.

\begin{tabular}{|c|c|c|c|}
\hline Variables & Frequency & Percentage & Mean \\
\hline \multicolumn{4}{|c|}{ Sex } \\
\hline Male & 100 & 100.0 & \\
\hline Female & 0 & 0 & \\
\hline \multicolumn{4}{|c|}{ Age (yrs) } \\
\hline $18-27$ & 30 & 30 & \\
\hline $28-37$ & 35 & 35 & \\
\hline
\end{tabular}




\begin{tabular}{|c|c|c|c|}
\hline $38-47$ & 25 & 25 & 31.2 \\
\hline $48-57$ & 9 & 9 & \\
\hline 58 years and above & 1 & 1 & \\
\hline \multicolumn{4}{|c|}{ Marital status } \\
\hline Married & 75 & 75 & \\
\hline Single & 25 & 25 & \\
\hline Divorced & 0 & 0 & \\
\hline Widow & 0 & 0 & \\
\hline \multicolumn{4}{|c|}{ Level of education } \\
\hline Formal education & 35 & 35 & \\
\hline Non-formal & 65 & 65 & \\
\hline \multicolumn{4}{|c|}{ Occupation } \\
\hline Farming & 60 & 60 & \\
\hline Fishing & 4 & 04 & \\
\hline Civil servant & 20 & 20 & \\
\hline Artisan & 6 & 06 & \\
\hline Trading & 10 & 10 & \\
\hline
\end{tabular}

Source: Field survey, 2016.

Mode of Land Acquisition, Farm Size and Animal Husbandry Practiced: Results in Table 2 depicts that majority (70\%) of the respondents acquired land through inheritance, $10 \%$ of them through purchased, $15 \%$ through rent, while $5 \%$ of the respondents acquired the land through gift. This finding depicts that the common mode of land acquisition in the study area was through inheritance and it could be due to the strict Islamic Shari'a Law based on which regulation mandates that a land belonging to the deceased person shall be distributed to his heirs accordingly. Findings in the Table Table 2. Distribution of Respondents According to Land Ac
2 further revealed that majority (76\%) of the respondents cultivated $1-3$ hectares of farmland and few $(3 \%)$ of them cultivated 10 hectares and above, implying that majority of the respondents in the study area were small scale farmers cultivating an average of 3 hectares and above of farmland. The small-scale nature of the farm size of the respondents could be attributed to some factors such as land tenure system and lack of capital. Also, findings in the Table indicated that $35 \%$ of the respondents reared cattle, $40 \%$ reared sheep, and $23 \%$ reared goat, while few $2 \%$ of them reared poultry.

\begin{tabular}{lccc}
\hline Variables & Frequency & Percentage & Mean \\
\hline Inherited & Land acquisition & & \\
Purchased & 70 & 70 \\
Rent & 10 & 10 \\
Gift & 15 & 15 & \\
\hline \multicolumn{5}{l}{3 ha } & 5 & & \\
$4-6$ ha & Farm size & 67 & 3.1 hectares \\
$7-10$ ha & 67 & 22 & \\
10 and Above & 22 & 8 & \\
\hline \multicolumn{5}{c}{ Cattle } & 8 & 3 & \\
Sheep & 3 & 35 & \\
Goat & Animal husbandry practiced & 40 \\
Poultry & 35 & 23 \\
\hline
\end{tabular}


Common Crop Residues Utilized: Findings in Table 3 indicated that $40 \%$ of the respondents utilized groundnut haulm in feeding their livestock and few (14\%) fed their livestock with maize stover. As could be seen from the findings, varieties of crop residues are used by the respondents in feeding their animals and commonly utilized animal residues are leguminous crop residues (groundnut and cowpea) and it could be due to high nutrition derived from it by the animals. According to Timothy et al. (1997), the availability of crop residues at the farm level depends not just on production levels but also on a variety of social and economic factors. Based on this assertion Akinola et al. (2015) reported that crop residues allocated for own animal feeding had the major share and farmers preferred using crop residues for feeding than mulching in northern Nigeria out of which legume residues for feed purposes attributed to about 64 percent of crop residues fed to animals. The findings also go contrary to Hart and McDowell (1985) reported that maize stover is the most important feed of livestock in the United State of America.

Table 3. Crop residues utilized in the study area.

\begin{tabular}{lcc}
\hline Variables & Frequency & Percentage \\
\hline Sorghum stalk & Crop Residues & \\
Maize Stover & 26 & 26 \\
Groundnut haulm & 14 & 14 \\
Cowpea and Millet & 40 & 40 \\
\hline
\end{tabular}

Sources of Crop Residues: Table 4 shows that majority $(80 \%)$ of the respondents obtained their crop residues from their farms, $5 \%$ of them purchase the residues and few (15\%) of the respondents indicated that they obtained the crop residue from both farmland and through purchase. Discussion with the respondents reveals that crop residues constitute a major source of feed for livestock in communal areas. According to the respondents, the major crop residues which are grazed or stockpiled for livestock feeding were millet, sorghum, cowpea vines, cowpea husks, maize stover, maize husk, and groundnut haulms but sorghum and millet crop residues were by far the most abundant of the cereal residues in the study area. Results further revealed that more than half (51\%) respondents reported that crop residues are more available during the harvest period only (3\%) of the respondents were of the opinion that the crop residues are more available at the onset of rainy season. These findings could be due to the fact majority of the farmers practiced mixed farming system and which help in getting variety of crop residues after harvesting. Results further indicate that $57.14 \%$ of the respondents in the study area opined that mixed cropping was the main source of crop residues in the study area while few $(3.57 \%)$ of the respondents were of the view that shifting cultivation provide more means towards availability of crop residues. Devendra et al. (1997) reported an important interaction between crop subsystem and that of animal subsystem showing a high dependence of animals on crop residues and strong dependence of cropping on animals for power in land preparation and fertilizer from manure dropped on fallow land while grazing. The interdependence of crops and livestock is primarily through dependence of animals on crop residues for feed and farmers manage individual cropping patterns (intercropped maize and beans, double cropped maize and cassava) to provide food and feed and neither crop nor livestock productivity can be increased without due consideration of the interaction between crops and livestock.

Crop Residues Storage and Preservation Methods: Proper arrangement in preservation of crop residue in the study area is usually carried out to minimize the loss of crop residues during storage and to maximize its availability to animals most especially during the dry season of the year. Results in Table 5 depicts that majority (71\%) of the respondents employed baling of the residues, $22 \%$ of them store and preserve the crop residues in silos while few $(7 \%)$ of the respondents use metallic drum to store and preserve the crop residues. 
Table 4. Distribution of Respondents According to Source of Crop Residues.

\begin{tabular}{|c|c|c|}
\hline Variables & Frequency & Percentage \\
\hline \multicolumn{3}{|c|}{ Source of crop residues } \\
\hline Farm & 80 & 80 \\
\hline Purchased & 5 & 5 \\
\hline All of the above & 15 & 15 \\
\hline \multicolumn{3}{|c|}{ Period of crop residue availability } \\
\hline Onset of rainy season & 3 & 3 \\
\hline Peak of rainy season & 31 & 31 \\
\hline Harvest period & 51 & 51 \\
\hline Dry season & 15 & 15 \\
\hline \multicolumn{3}{|c|}{ Farming system that provides more crop residues } \\
\hline$\overline{\text { Mono cropping }}$ & 25 & 17.85 \\
\hline Mixed cropping & 80 & 57.14 \\
\hline Shifting cultivation & 5 & 3.57 \\
\hline Crop rotation & 20 & 14.29 \\
\hline Mixed farming & 10 & 7.14 \\
\hline
\end{tabular}

Source: Field survey, 2016; *Multiple response

Table 5. Storage and Preservation of Crop Residues.

\begin{tabular}{lcc}
\hline Variables & Frequency & Percentage \\
\hline Baling of the residues & 71 & 71.0 \\
Stored and preserved in silos & 22 & 22.0 \\
Stored and preserved metallic drum & 7 & 7.0 \\
\hline
\end{tabular}

Source: Field survey, 2016.

Findings of the study imply that the preservation methods employed by majority of the respondents do not lead to avoidance of spoilage and maintenance of the nutrient contents of the residues. Literature search conducted on the subject matter suggested the under listed methods of storage and preservation of the crop residues for the best retention of quality and quantity. With available technologies the under listed storage and preservation systems are suggested to the respondent sin the study area:

Round Bale Storage Systems: A well-designed hay storage system provides for protection from moisture to all sides of a hay bale, provides ventilation around the bale for moisture removal during the curing phase after baling, and facilitates the removal of moisture condensation caused by the daily heating and cooling of hay (Huhnke, 2017).

Plastic Net Wrap: Plastic net wrap on large round hay bales helps prevent water from penetrating the hay bale by uniformly compressing the outer surface providing a dense outer layer that tends to shed rainfall
(Thomas, 2017).

Twine Wrapped: Crop residue spoilage can be reduced to less than $5 \%$ by storing hay under a shed or covering it with plastic and elevating it above ground moisture. A hay storage system, even when using plastic coverings, should provide as much air movement around the bale as possible. Therefore, bale weight losses during inside storage are primarily moisture losses, and do not indicate excessive dry matter losses. Plastic sheeting used for protecting hay bales stored outside should be secured above ground level to allow the soil under the bale to dry and to allow air currents to evaporate any condensation between the bale and plastic coverings (KUHN, 2017)

Plastic Stretch Wrap: Plastic stretch wrap is best used for storing high-moisture forages where adequate drying time is not available to produce dry hay. High-moisture forage can often be baled as hay and wrapped 12-24 hours. Fermentation of the haylage, similar to silage, is complete after a 3-week storage period at which time feeding may begin. In most cases, the sooner these bales 
are fed, the less chance there is for them to have spoilage losses caused by a loss of their anaerobic condition (i.e. tears or breaks in the plastic sheeting). (Stretch Wrap, 2017)

Plastic Wrap on Dry Hay: If plastic wrap is used on dry hay, hay should be as dry as possible at the time of wrapping to prevent excessive bale heat and moisture collection during curing.

Remember, a 1,500-pound bale will attempt to shed about 12-13 gallons of water. Also, plastic should not be allowed to curl over the ends of the bales because this allows the wrap to catch and trap moisture against the hay. Plastic-wrapped bales should not be stored end to end before the bale is fully cured to allow for improved air circulation (Martinso et al., 2017).

Bale Bags: Individual hay bale bags that can be made air tight are best used for high-moisture bales and are commonly referred to as baleage. Early spring forages can be stored using this method when climatic conditions would prevent making dry hay. Two disadvantages to bale bags are their relatively high cost and the need to feed baleage or haylage as quickly after fermentation as possible (Bale bags, 2017)
Respondents' perception on the relevance of crop residues as animal feed: Results in Table 5 show the perception of the respondents on the role of crop residues as source of feeds for animals. Three points Likert rating scale was used to measure the perception of the respondents towards the subject matter. Findings of the research revealed that majority $(90 \%)$ of the respondents were of the view that large proportion of metabolizable energy (ME) is wasted during eating and digestion of low quality crop residues, $87 \%$ of them opined that the net energy content of a crop residues depends on the concentration of digestible energy in it, while $85 \%$ of the respondents perceived that farm animals that are fed with crop residues usually produce high yield and better quality milk and beef.

Findings from the study further revealed that crop residues from dual-purpose crops, particularly from coarse cereal and leguminous crops, are by far the most important feed source available to farmers in the study area. The result of the study further shows that $60 \%$ of total feed provided to the animals in the study area were obtained from crop residues due to long dry season experience.

Table 6. Respondents' perceptions on the relevance of crop residue as animal feed.

\begin{tabular}{|c|c|c|c|c|}
\hline \multirow{2}{*}{ S/No } & \multirow[b]{2}{*}{ Attitudinal statements } & \multicolumn{3}{|c|}{ Respondents Perceptions } \\
\hline & & $\begin{array}{l}\text { Agree } \\
\text { (A) }\end{array}$ & $\begin{array}{l}\text { Undecided } \\
\text { (U) }\end{array}$ & $\begin{array}{l}\text { Disagree } \\
\text { (DA) }\end{array}$ \\
\hline 1 & $\begin{array}{l}\text { Farm animals are fed with crop residue to provide better quality } \\
\text { milk and beef. }\end{array}$ & $85(85)$ & $0(0)$ & $15(15)$ \\
\hline 2 & Crop residue is cheap and affordable & $80(80)$ & $5(5)$ & $15(15)$ \\
\hline 3 & $\begin{array}{l}\text { Luxuriant state of crop residue indicates its capability to supply } \\
\text { the nutritional demands of animals }\end{array}$ & $35(35)$ & $0(0)$ & $65(65)$ \\
\hline 4 & $\begin{array}{l}\text { The net energy content of a crop residue depends on the } \\
\text { concentration of digestible energy in it }\end{array}$ & $87(87)$ & $8(8)$ & $5(5)$ \\
\hline 5 & $\begin{array}{l}\text { Large proportion of metabolizable energy is wasted during eating } \\
\text { and digestion of low-quality crop residues. }\end{array}$ & $90(90)$ & $0(0)$ & $0(10)$ \\
\hline 6 & $\begin{array}{l}\text { Intake and digestibility of crop residues are adversely affected } \\
\text { when mineral content of the crop residue drops below the level } \\
\text { required for animal growth }\end{array}$ & $20(20)$ & $0(0)$ & $80(80)$ \\
\hline 7 & Crop residue serves as sources of income to farmers & $80(80)$ & $3(3)$ & $17(17)$ \\
\hline \multirow[t]{2}{*}{8} & $\begin{array}{l}\text { Crop residues quality can be influenced by level of soil fertility and } \\
\text { prevailing climatic condition }\end{array}$ & $96(96)$ & $0(0)$ & $4(40)$ \\
\hline & Total Score & 573 & 16 & 201 \\
\hline
\end{tabular}




\section{CONCLUSION}

Study concluded that making crop residues available for animal feeding in the study area was a male dominated activity, majority of who were active in age and having non - formal education. Findings of the study also concluded that the common mode of acquiring land in the study area was through inheritance with small farm holdings and common animal husbandry practiced by the respondents was raising sheep and cattle. Finally, the study concluded that groundnut haulms and sorghum stalks were the common crop residues utilized for feeding animals, mostly stored and preserved locally with the use of silos and drums and majority of the respondents perceived that large proportion of metabolizable energy is wasted during eating and digestion of low-quality crop residues.

Recommendations: Base on the findings of the research, the following recommendations are suggested purposely to improve the availability and nutrient content of crop residues:

-There is need to encourage and motivate females and other vulnerable groups to participate in crop residues production, preservation and storage.

-Chemical and biological methods of selecting crop residues with higher nutritive value need to be introduced to the farmers in order to select, preserve and store their crop residues.

-Government and the respondents are advice to come up with modern storage and preservation methods of crop residues in order to improve its nutrient value and avoid spoilage.

-There is need for extension workers to train farmers the need for timely harvesting of their crops so as to provide their animals with a high valued crop residue

\section{REFERENCES}

Agyemang, K., Clifford, D. J., \& Little, D. A. (1993). An assessment of the biological and economic efficiency in conversion of milk to meat in N'Dama calves. Animal Production, 56,165-170.

Akinola, A. A., Ayedun, B., Abubakar, M., Sheu, M. \& Abdoulaye, T. (2015). Crop residue usage and its determinants in Kano State, Nigeria. Journal of Development and Agricultural Economics, 7(4), 162-173.

Alemu, T., Chairatanayuth, P., Vijchulata, P. \& Tudsri, S. (2006). Production and utilization of crop residues in three agro ecological zones of Eastern Shoa zone, Ethiopia. Kasetsart J. (Nat. Sci.), 40, 643 - 651.
Arntzen CJ. 1994. Encyclopedia of agricultural science. Boca Raton (FL): Academic Press, 34

Bale bags (2017). Accessed from http://farmbagsupplystore.com/balebags.html on $25 / 12 / 2017$ at $07: 16 \mathrm{am}$

Blum, M. L. \& Naylor, J. C (1984). Industrial psychology, CBS Publishers and Distributors Delhi: 1-2

Cook, B. G., Pengelly, B. C., Brown, S. D., Donnelly, J. L., Eagles, D. A., Franco, M. A., Hanson, J., Mullen, B. F., Partridge, I. J., Peters, M. \& Schultze-Kraft, R. (2005). Tropical forages. CSIRO, DPI\&F (Qld), CIAT and ILRI, Brisbane, Australia.

Deaville, E. R., Moss, A. R. \& Givens, D. I. (1994). The nutritive value and chemical composition of energy-rich by-products for ruminants. Anim. Feed Sci. Technol., 49, 261-276.

Devendra, C., Thomas, D., Jabar, M. A and Kudo, H. (1997). Improvement of livestock production in crop-animal system in rainfed agro-ecological zones of South-east Asia. International Livestock Research Institute-ILRI, Nairobi, Kenya, 116.

FAO, (2013). Grassland index. A searchable catalogue of grass and forage legumes. FAO, Rome, Italy

Fialho, E. T., Barbosa, H. P., Albino, L. F. T. (1995). Chemical composition, digestible protein and energy values of some alternative feedstuffs for pigs in Brazil. Anim. Feed Sci. Technol., 55 (3-4): 239-245.

Göhl, B. (1982). Les aliments du bétail sous les tropiques. FAO, Division de Production et Santé Animale, Roma, Italy.

Heart, R. \& McDowell, R. E (1985). Crop/livestock interactions as determinants of crop and livestock production. Cornell University Agriculture Mimeo 107, Cornell University, Ithaca, N.Y, U.S.A.

Huhnke, R. L. (1993). Round ale orientation effects alfalfa hay storage. Applied Engineering in Agriculture, 9(4), 349-3.

KHUHN RW (2017). E- twin Round Bale Wrappers. Accessed from https://www.google.com/search?ei=9Vk_WoHFB YLDgAaZu6XICw\&q=Twin+wrap+bale\&oq=Twin+ wrap+bale\&gs_l=psy- on 24/12/2017 at 09:07am

Kossila, V. (2018). The availability of crop residues in developing countries in relation to livestock production. Accessed from www.fao.org/wairdocs/ILRI/X5495e/03.htm on $20 / 04 / 2018$ at $4.34 \mathrm{Pm}$ 
Madamba, R., Grubben, G. J. H., Asante, I. K., Akromah, R. (2006). Vigna unguiculata (L.) Walp. Record from Protabase. Brink, M. \& Belay, G. (Editors). PROTA (Plant Resources of Tropical Africa / Ressources végétales de l'Afrique tropicale), Wageningen, Netherlands

Martinson, K., Sheaffer, C. \& Coblentz, W. (2017). Harvest moisture and bale wrapping affects forage quality and mold in grass round-bales. Accessed from https://www.extension.umn.edu/agriculture/hor se/nutrition/bale-wrapping-affects-foragequality/ on 25/12/2017 at 07:09am

Nations Encyclopedia (2018). Nigeria agriculture, information about agriculture in Nigeria. Accessed from

www.nationsencyclopedia.com/economies/Africa /Nigeria-AGRICULTURE.html on 19/04/2018 at 11:54Am.

Online Nigeria (2018). Kebbi state natural resources and development. Accessed from https:// onlinenigeriacom/Kebbi-state/?blurb=303 on 21/04/2018 at 06:32Am.

Onwuka, C. F. I., Adetiloye, P. O. and Afolani, C. A. (1997). Use of household wastes and crop residues in small ruminants feeding in Nigeria. Small Ruminants Research, 24(3), 233-237.

Renard, C. (1997). Crop residues in sustainable mixed crop/livestock farming systems. Birdles Ltd, UK, accessed from https:// cigars.org/bitstream/handle/10568/49684/crop residues.pdf. jsessionid on 20/04/2018 0n 5:03Pm.

Stretch Wrap (2017). Accessed from http://www.farmbagsupply.com/sunfilm.htm on 25/12/2017 at 06:59am

Suttie, J. M. (2000). Hay crops-legumes and pulses. In: Hay and Straw Conservation-For Small-Scale Farming and Pastoral Conditions. FAO Plant Production and Protection Series No. 29, FAO, Rome.

Thomas, S. H. (2017). Software disease - the hazards of plastic, net wrap and twines. Accessed from https://www.canadiancattlemen.ca/2017/09/13 /the-hazards-of-plastic-net-wrap-and-twine-forcattle-feeding/ on 24/12/2017 at 09:17am

Timothy, O.W., Fernandez-Rivera, S. \& Timothy, G.K. (1997). The influence of socioeconomic factors on the availability and utilization of crop residues as animal feeds. Retrived from http://www. Ilri.cgair.org/inforsserve/webpub/fulldocs/cropr esidues/chap\%202, htm on $25 / 12 / 2017$ at 10:24am.

Van - Rij, N. (1999). Production of cowpea in KwazuluNatal. Agriculture and Environment Affairs Department, Province of Kwazulu-Natal, SouthAfrica. 